\title{
Spatial distribution of Phyllocnistis citrella Stainton (Lepidoptera: Gracillariidae) larvae in three scales
}

\author{
Jesus, CR. ${ }^{\mathrm{a}}$ and Redaelli, LR. . $^{\mathrm{b}}$ **

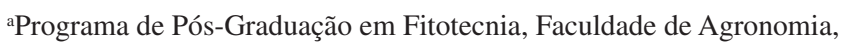 \\ Universidade Federal do Rio Grande do Sul - UFRGS, \\ Av. Bento Gonçalves, 7712, CEP 91540-000, Porto Alegre, RS, Brazil \\ ${ }^{\text {b}}$ Departamento Fitossanidade, Faculdade de Agronomia - UFRGS, \\ Av. Bento Gonçalves, 7712, CEP 91540-000. Porto Alegre, RS, Brazil \\ *e-mail: luredael@ufrgs.br
}

Received June 19, 2006 - Accepted September 18, 2006 - Distributed February 29, 2008

(With 1 figure)

\begin{abstract}
The spatial distribution of larvae of Phyllocnistis citrella Stainton (Lepidoptera: Gracillariidae), the citrus leaf miner, in leaves, shoots, and tree crowns of Montenegrina tangerine (Citrus deliciosa Tenore) and Murcott tangor (Citrus sinensis L. Osbeck x Citrus reticulata Blanco) was determined. Fortnightly samplings from July/2001 to June/2003,

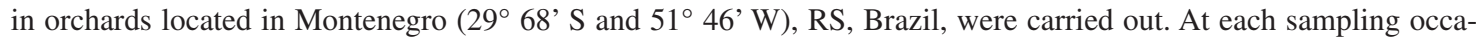
sion eighth shoots randomly selected were collected. The spatial distribution pattern of $P$. citrella larvae between tree crowns and in the shoots was aggregated in most sampling occasions in both citrus species. Nevertheless, on the leaves, this pattern followed a random distribution, as indicated by the indices $\mathrm{I} \mathrm{I}_{\delta}$ and $\mathrm{k}$ parameter.
\end{abstract}

Keywords: citrus leafminer, spatial distribution, 'Montenegrina', 'Murcott'.

\section{Distribuição espacial das larvas de Phyllocnistis citrella Stainton (Lepidoptera: Gracillariidae) em três escalas}

\section{Resumo}

Com o objetivo de determinar a distribuição espacial das larvas de Phyllocnistis citrella Stainton, (Lepidoptera: Gracillariidae), o minador-dos-citros, nas folhas, nos brotos e nas copas das plantas de tangerineira 'Montenegrina' (Citrus deliciosa Tenore) e de tangor 'Murcott' (Citrus sinensis L. Osbeck x Citrus reticulata Blanco), foram realizadas amostragens quinzenais de julho de 2001 a junho de $2003 \mathrm{em}$ pomares localizados em Montenegro (29 $68^{\prime} \mathrm{S}$ e $51^{\circ} 46^{\prime}$ W), RS, Brasil. Em cada ocasião de amostragem foram coletados aleatoriamente oito brotos. Através da análise, pelos índices de dispersão I e $\mathrm{I}_{\delta}$, o padrão de distribuição espacial das larvas de $P$. citrella entre as plantas e nos brotos de 'Montenegrina' e 'Murcott' foi agregado na maioria das ocasiões de amostragem. O padrão de distribuição espacial das larvas do minador-dos-citros nas folhas mostrou-se diferente do registrado em copas das plantas e brotos, os índices I, I $\mathrm{I}_{\delta}$ e o parâmetro k indicaram distribuição aleatória.

Palavras-chave: minador-dos-citros, distribuição espacial, 'Montenegrina', 'Murcott'.

\section{Introduction}

The spatial distribution of a population, that is, the position that individuals occupy in environment ones relative to the others, at a given time, is a central issue in population dynamics studies. A population may show three basic patterns of distribution: random, uniform (regular) and aggregated (clustered). The pattern may change in time, among developmental stages of a same species or even occur superposed in a given population (Southwood, 1978; Elliott, 1983). The identification of the distribution pattern is essential to the development of sampling programs, especially those involving species considered pests (Davis, 1993).

The citrus leafminer, Phyllocnistis citrella Stainton (Lepidoptera: Gracillariidae), has been considered one

of the most important pests of the citrus culture, occurring practically worldwide (Heppner, 1993; Amalin et al., 2002). The eggs are placed in new leaves (shoots) and the larvae feed under the leaf epidermis making galleries or mines. The epidermis detaching may cause a reduction of the photosynthetic area and leaf curling causing losses mainly in nurseries and young orchards (Schaffer et al., 1997; Volpe et al., 1998). Indirectly, the chief damage caused by $P$. citrella facilitates the entrance of the bacteria Xanthomonas axonopodis pv. citri (Hasse) Vauterin et al., the causal agent of the citric canker (Chagas et al., 2001; Amaral, 2003). This disease is responsible for serious economic losses because fruit spoilage depreciates its commercial value. Besides this, the control of this 
disease is difficult, the eradication of the affected plants being the main measure (Amaral, 2003).

The spatial distribution of the immature stages of $P$. citrella have been studied in several citrus cultivars and in different spatial scales, mainly in the USA (Knapp, 1995), in India (Rao et al., 2002) and in Brazil (Dantas, 2002).

This study aimed to determinate the spatial distribution of $P$. citrella larvae on leaves, on shoots and on plants of 'Montenegrina' tangerine and 'Murcott' tangor, in orchards under organic management, in Montenegro, RS.

\section{Material and Methods}

The samplings were carried out in an orchard of 'Montenegrina' tangerine trees and in other of the hybrid 'Murcott' (Citrus sinensis L. Osbeck x Citrus reticulata Blanco), located at Montenegro (29 $68^{\prime} \mathrm{S}$ and $\left.51^{\circ} 46^{\prime} \mathrm{W}\right), \mathrm{RS}$, Brazil.

Each orchard, with an area of 0.6 ha, comprehends 315 plants, 12 years old, spaced $3 \mathrm{~m}$ between plants and $6 \mathrm{~m}$ between rows. The orchards are maintained under organic management since their implantation.

The orchards were subdivided in three subareas approximately 0.2 ha each with a similar number of plants to ensure that all the area be represented in the samplings. Fortnightly samplings were carried out from July 2001 to June 2003, and in each occasion 12 plants were randomly selected, being four in each subarea. At each selected plant, if present, eight shoots were collected.

The collected shoots were individually packed in labeled plastic bags, stored in thermal box and transported to the laboratory.
At the laboratory, with the aid of a stereomicroscope Leica MZ 12, each leaf was examined and the number of larvae per leaf registered.

The spatial distribution of $P$. citrella larvae was analyzed in the leaves, shoots and tree crowns, only on those sampling occasions when the number of individuals (n) was higher than eight. It was calculated the ratio between the variance and the sample average (I), the Morisita Index $\left(\mathrm{I}_{\delta}\right)$ and the k parameter of the Negative Binomial, using the software Ecological Methodology (Krebs, 2000). Values of $\mathrm{I}$ and $\mathrm{I}_{\delta}$ equal to unity indicates a random distribution, lesser than one a uniform distribution and significantly higher than one an aggregated distribution. Otherwise, values of $0<\mathrm{k} \leq 8$ indicate a random distribution (Poole, 1974). Significance was tested by the $\chi$-square $(\alpha=0.05)$.

The dispersion index of Iwao was calculated by the ratio of the accumulated average $\left(\mathrm{x}^{\prime}=\overline{\mathrm{x}}+\left[\left(\mathrm{s}^{2} / \overline{\mathrm{x}}\right)-1\right]\right)$ and the average $(\overline{\mathrm{x}})$, resulting in the linear equation: $x^{\prime}=\beta \bar{x}+\alpha$, where $\beta$ gives the aggregation coefficient (Southwood, 1978; Elliott, 1983).

\section{Results and Discussion}

Along the two study years 53 sampling occasions occurred. In 'Montenegrina' orchard, 1,487 shoots were collected totaling 7,313 examined leaves and 767 larvae of $P$. citrella registered. In 'Murcott' orchard, were collected 1,045 shoots, 4, 536 leaves and 655 larvae.

The greatest number of larvae was registered in summer and in autumn either in 'Montenegrina' as in 'Murcott' (Table 1). In both orchards, along the study there was a marked decrease of the citrus leaf miner

Table 1. Number of Phyllocnistis citrella larvae (n), I index (I), Morisita $\left(\mathrm{I}_{\delta}\right)$ and $\mathrm{k}$ parameter of the Negative Binomial distribution $(\mathrm{k})$, used to determine the spatial distribution of larvae in tree crowns of Montenegrina (Citrus deliciosa Tenore) and of the hybrid Murcott (Citrus sinensis $\mathrm{x}$ Citrus reticulata), chi-square test $\left(\chi^{2}\right)$ to test the goodness of fit of the observed distributions and probability (P), from July 2001 to June 2003, Montenegro (29 $68^{\prime}$ S and 51 $46^{\prime}$ W), RS.

\begin{tabular}{|c|c|c|c|c|c|c|c|c|c|c|c|c|}
\hline & \multicolumn{6}{|c|}{ 'Montenegrina' } & \multicolumn{6}{|c|}{ 'Murcott' } \\
\hline & $\mathbf{n}$ & $\mathbf{I}$ & $\mathbf{I}_{\delta}$ & $\chi^{2}$ & $\mathbf{P}$ & $\mathbf{k}$ & $\mathbf{n}$ & $\mathbf{I}$ & $\mathrm{I}_{\delta}$ & $\chi^{2}$ & $\mathbf{P}$ & $\mathbf{k}$ \\
\hline $15 / 10 / 2001$ & - & - & - & - & - & - & 9 & 0.95 & 0.90 & 7.6 & 0.52 & 1.89 \\
\hline $12 / 11 / 2001$ & 11 & 3.31 & 2.61 & 23.1 & 0 & 0.73 & 29 & 6.50 & 1.78 & 26 & 0 & 1.81 \\
\hline $26 / 11 / 2001$ & 27 & 8.83 & 4.01 & 88.2 & 0 & 0.35 & 11 & 2.61 & 2.29 & 20.9 & 0 & 0.92 \\
\hline $10 / 12 / 2001$ & - & - & - & - & - & - & 11 & 4.23 & 2.61 & 21.1 & 0 & 0.74 \\
\hline $26 / 12 / 2001$ & 45 & 6.08 & 3.88 & 152 & 0 & 0.35 & - & - & - & - & - & - \\
\hline $07 / 01 / 2002$ & 19 & 5.86 & 2.35 & 29.3 & 0 & 0.88 & 26 & 5.52 & 2.91 & 60.7 & 0 & 0.54 \\
\hline $21 / 01 / 2002$ & - & - & - & - & - & - & 29 & 2.55 & 1.66 & 30.6 & 0 & 1.76 \\
\hline $04 / 02 / 2002$ & 60 & 4.59 & 1.54 & 41.3 & 0 & 2.29 & - & - & - & - & - & - \\
\hline 04/03/2002 & - & - & - & - & - & - & 28 & 3.91 & 1.64 & 23.5 & 0 & 2.09 \\
\hline $18 / 03 / 2002$ & - & - & - & - & - & - & 17 & 2.11 & 1.69 & 21.1 & 0.01 & 1.75 \\
\hline $01 / 04 / 2002$ & 97 & 5.55 & 1.53 & 66.3 & 0 & 2.06 & 78 & 4.12 & 1.44 & 45.3 & 0 & 2.82 \\
\hline $15 / 04 / 2002$ & 31 & 4.12 & 2.66 & 66.0 & 0 & 0.64 & 69 & 9.23 & 2.81 & 138.5 & 0 & 0.57 \\
\hline $29 / 04 / 2002$ & 12 & 1.51 & 1.69 & 22.6 & 0.09 & 1.72 & 29 & 3.59 & 2.20 & 46.7 & 0 & 0.91 \\
\hline $13 / 05 / 2002$ & 9 & 1.80 & 1.50 & 9 & 0.10 & 3.6 & 8 & 2.75 & 2.50 & 16.5 & 0.01 & 0.83 \\
\hline $25 / 11 / 2002$ & 16 & 2 & 1.47 & 14 & 0.05 & 3.22 & - & - & - & - & - & - \\
\hline $09 / 12 / 2002$ & 44 & 2.14 & 1.31 & 25.7 & 0.01 & 4.30 & - & - & - & - & - & - \\
\hline $20 / 12 / 2002$ & 44 & 3.18 & 1.72 & 44.6 & 0 & 1.58 & - & - & - & - & - & - \\
\hline $06 / 01 / 2003$ & 191 & 5.51 & 1.57 & 132 & 0 & 1.89 & 83 & 4.15 & 1.26 & 29.0 & 0 & 7.83 \\
\hline $21 / 01 / 2003$ & 118 & 12.10 & 1.66 & 84.4 & 0 & 190 & 66 & 5.76 & 1.73 & 57.6 & 0 & 1.58 \\
\hline $03 / 02 / 2003$ & 67 & 3.66 & 1.44 & 40.2 & 0 & 2.85 & 67 & 3.50 & 1.60 & 56.0 & 0 & 1.85 \\
\hline $17 / 02 / 2003$ & 16 & 2.06 & 1.38 & 18.6 & 0.02 & 3.75 & - & - & - & - & - & - \\
\hline $17 / 03 / 2003$ & - & - & - & - & - & - & 15 & 1.80 & 2.09 & 12 & 0.21 & 1.02 \\
\hline $28 / 04 / 2003$ & 15 & 1.40 & 1.14 & 7 & 0.21 & -18 & 20 & 1.33 & 1.15 & 34.3 & 0.01 & 22.2 \\
\hline
\end{tabular}


population in the winter $(n<8$ in every sampling occasion).

The analysis through the dispersion indexes $\mathrm{I}$ and $\mathrm{I}_{\delta}$ and the spatial distribution pattern of $P$. citrella larvae in plants of 'Montenegrina' cultivar, revealed an aggregated distribution in $100 \%$ of the sampling occasions and in only three occasions was not detected significance (Table 1).

In plants of the tangor 'Murcott' in 17 occasions the distribution pattern was aggregated and in two it was random. The $\mathrm{k}$ parameter also indicated the aggregated distribution as the most frequent pattern, in just one occasion a random distribution was registered (Table 1). Dantas (2002) obtained a similar result, which registered an aggregated distribution pattern of the $P$. citrella larvae in orchards of 'Pera-Rio' orange in São Paulo state. The aggregation observed in both studies may be resultant of an intrinsical behavior of the individuals and/or a response to the food and habitat resources distribution. Concentration of a suitable resource in some areas has been considered as the prevailing cause of aggregation of most organisms (Ricklefs and Miller, 2000). According to Knapp (1995), the citrus leaf miner distribution among plants seems to be related to the availability of shootings in the plant, which may differ among them.

In 'Montenegrina' shootings, it was observed an aggregated distribution pattern through the use of index I in $94.7 \%$ of the sampling occasions (Table 2). Otherwise, the Morisita index rendered an aggregated distribution in $84.2 \%$, random in $10.5 \%$ and regular in $5.3 \%$ of the sam- pling occasions. The $\mathrm{k}$ parameter indicated aggregated distribution in $89.5 \%$ and random in $5.9 \%$.

In the 'Murcott' orchard, indexes I and $\mathrm{I}_{\delta}$ revealed an aggregated distribution in $88.2 \%$ and regular in $11.8 \%$ of the sampling occasions. Considering the k parameter, $94.1 \%$ and $5.9 \%$ of the occasions showed respectively an aggregated and a regular distribution. These results indicate that besides the preference for some plants in the orchard there is also a selection of most suitable areas to the offspring in the host plant. Dantas (2002) also registered an aggregated distribution pattern of larvae in shoots. Otherwise Knapp (1995) in a study realized in southern Florida in lime orchards, found a regular distribution pattern in shoots.

The spatial distribution pattern of the citrus leaf miner larvae, in leaves, was different from those found in plants and shoots. In 'Montenegrina', the indexes I and $\mathrm{I}_{\delta}$ and the $\mathrm{k}$ parameter indicated a random distribution in $77.7 \%$ and aggregated in $22.2 \%$ of the sampling occasions (Table 3). In 'Murcott', it was registered a random distribution in $64.7 \%$ and aggregated in $35.3 \%$. The $\mathrm{k}$ parameter evidenced that in $52.9 \%$ of the sampling occasions the distribution was random and in $47 \%$ aggregated. This pattern observed in leaves reflects one of the strategies showed by miner insects to maintain the population, considering that competition by interference in leaves with numerous mines represents one of the main mortality factors. Aggregation could increase the occurrence of intraspecific interference (Auerbach et al., 1995). Rao et al. (2002), in a study carried out in

Table 2. Number of Phyllocnistis citrella larvae (n), I index (I), Morisita $\left(\mathrm{I}_{\delta}\right)$ and k parameter of the Negative Binomial distribution (k), used to determine the spatial distribution of larvae in shoots of Montenegrina trees (Citrus deliciosa) and of the hybrid Murcott (Citrus sinensis $\times$ Citrus reticulata), chi-square test $\left(\chi^{2}\right)$ to test the goodness of fit of the observed distributions and probability (P),from July 2001 to June 2003, Montenegro (29 $68^{\prime}$ S and 51 $\left.46^{\prime} \mathrm{W}\right)$, RS.

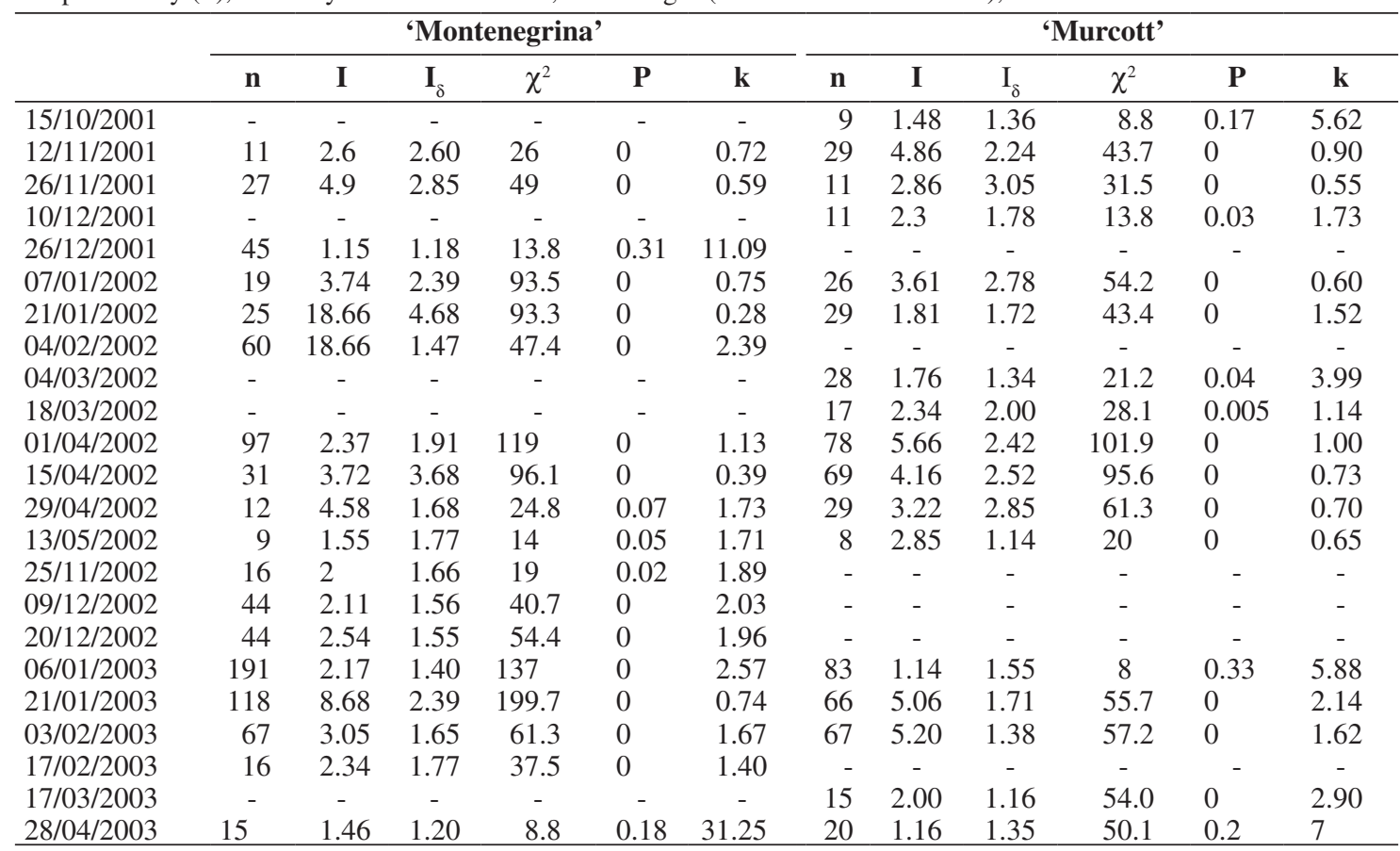


Table 3. Number of Phyllocnistis citrella larvae (n), I index (I), Morisita $\left(\mathrm{I}_{\delta}\right)$ and $\mathrm{k}$ parameter of the Negative Binomial distribution $(\mathrm{k})$, used to determine the spatial distribution of larvae in leaves of Montenegrina trees (Citrus deliciosa) and of the hybrid Murcott (Citrus sinensis $\times$ Citrus reticulata), chi-square test $\left(\chi^{2}\right)$ to test the goodness of fit of the observed distributions and probability (P), from July 2001 to June 2003, Montenegro (29 $68^{\prime} \mathrm{S}$ and $\left.51^{\circ} 46^{\prime} \mathrm{W}\right)$, RS.

\begin{tabular}{|c|c|c|c|c|c|c|c|c|c|c|c|c|}
\hline & \multicolumn{6}{|c|}{ 'Montenegrina' } & \multicolumn{6}{|c|}{ 'Murcott' } \\
\hline & $\mathbf{n}$ & I & $\mathbf{I}_{\delta}$ & $\chi^{2}$ & $\mathbf{P}$ & $\mathbf{k}$ & $\mathbf{n}$ & I & $\mathrm{I}_{\delta}$ & $\chi^{2}$ & $\mathbf{P}$ & $\mathbf{k}$ \\
\hline $15 / 10 / 2001$ & - & - & - & - & - & - & 9 & 1.17 & 1.22 & 11.7 & 0.29 & 9.11 \\
\hline $12 / 11 / 2001$ & 11 & 1.57 & 2.23 & 44 & 0.02 & 0.9 & 29 & 1.84 & 1.57 & 35.1 & 0.01 & 1.97 \\
\hline $26 / 11 / 2001$ & 27 & 2.77 & 1.12 & 58.1 & 0 & 2.87 & 11 & 1.67 & 1.41 & 29.1 & 0.25 & 2.90 \\
\hline $10 / 12 / 2001$ & - & - & - & - & - & - & 11 & 0.95 & 0.92 & 15.2 & 0.50 & -8.10 \\
\hline $26 / 12 / 2001$ & 45 & 0.77 & 0.41 & 23.9 & 0.81 & -1.7 & - & - & - & - & - & - \\
\hline $07 / 01 / 2002$ & 19 & 1.10 & 1.12 & 75.2 & 0.25 & 9.05 & 26 & 0.84 & 0.82 & 21.0 & 0.68 & -4.79 \\
\hline $21 / 01 / 2002$ & - & - & - & - & - & - & 29 & 0.96 & 0.91 & 65.6 & 0.55 & 10.16 \\
\hline $04 / 02 / 2002$ & 60 & 7.53 & 1.25 & 444 & 0 & -1.8 & - & - & - & - & - & - \\
\hline $04 / 03 / 2002$ & - & - & - & - & - & - & 28 & 0.66 & 0.73 & 14.7 & 0.87 & -3.28 \\
\hline $18 / 03 / 2002$ & - & - & - & - & - & - & 17 & 0.71 & 0.29 & 22.7 & 0.911 & -1.45 \\
\hline $01 / 04 / 2002$ & 97 & 0.88 & 0.91 & 62.6 & 0.74 & -10 & 78 & 1.35 & 1.21 & 66.2 & 0.05 & 5.11 \\
\hline $15 / 04 / 2002$ & 31 & 1.27 & 1.72 & 100.6 & 0.05 & 1.4 & 69 & 1.33 & 1.46 & 94.7 & 0.03 & 2.25 \\
\hline $29 / 04 / 2002$ & 12 & 0.92 & 0.69 & 41.6 & 0.61 & -3.3 & 29 & 1.40 & 1.52 & 60.5 & 0.04 & 1.71 \\
\hline $13 / 05 / 2002$ & 9 & 0.89 & 0.8 & 15.2 & 0.58 & -4.2 & 8 & 1.5 & 1.85 & 18 & 0.11 & 1.46 \\
\hline $25 / 11 / 2002$ & 16 & 0.67 & 0.55 & 14.2 & 0.85 & -2.1 & - & - & - & - & - & - \\
\hline $09 / 12 / 2002$ & 44 & 0.66 & 0.64 & 31.2 & 0.96 & -2.7 & - & - & - & - & - & - \\
\hline $20 / 12 / 2002$ & 44 & 0.46 & 0.20 & 30.9 & 0.99 & -1.2 & - & - & - & - & - & - \\
\hline $06 / 01 / 2003$ & 191 & 0.94 & 0.91 & 250 & 0.75 & -10 & 83 & 0.95 & 0.97 & 44.8 & 0.56 & -21.00 \\
\hline $21 / 01 / 2003$ & 118 & 15.37 & 1.38 & 191 & 0 & 3.3 & 66 & 2.21 & 1.71 & 86.4 & 0.00 & -1.46 \\
\hline $03 / 02 / 2003$ & 67 & 0.56 & 0.50 & 35.8 & 0.99 & -1.9 & 67 & 0.77 & 0.75 & 59.7 & 0.92 & -3.90 \\
\hline $17 / 02 / 2003$ & 16 & 0.54 & 0 & 30 & 0.99 & -1.0 & - & - & - & - & - & - \\
\hline $17 / 03 / 2003$ & - & - & - & - & - & - & 15 & 0.52 & 0.33 & 18.3 & 0.99 & -1.49 \\
\hline $28 / 04 / 2003$ & 15 & 0.55 & 0.61 & 3.6 & 0.87 & -2.2 & 20 & 1.25 & 1.94 & 101.7 & 0.05 & 1.12 \\
\hline
\end{tabular}

India, verified that in low densities $P$. citrella present an aggregated distribution in leaves, and at high densities it is random.

The $\beta$ values and the determination coefficients obtained through Iwao regression in tree crowns $(\beta=1.40$ and $\beta=1.17)$ and shoots $(\beta=3.25$ and $\beta=1.54)$ of 'Montenegrina' (Figure 1a,c) and 'Murcott' (Figure 1b,d), respectively, indicated that larval distribution was aggregated in these levels along all the sampling period.

The aggregation coefficient of the larval distribution on the leaves of 'Montenegrina' trees (Figure 1e) was near one $(\beta=0.09$ ) but not significant, nevertheless indicating a trend to a regular distribution. Otherwise, in 'Murcott' tree crowns, this coefficient denoted an aggregated distribution of $P$. citrella larvae in the leaves ( $\beta=1.31$ ) (Figure 1f).

The results obtained in the present study corroborate the findings of Hespenheide (1991), which emphasize that the spatial distribution of miners insects should be approached at different spatial scales, considering that in a given habitat the distribution is not homogeneous. The mine distribution is determined by the oviposition preference of the adults (Mopper et al., 1984). According to
Faeth (1990), aggregation in miner insects is widespread, because the immature stages are usually sedentary due to their feeding habit. Meanwhile, the formation of aggregates in individual leaves could result in an increase of the intraspecific competition or cannibalism (Auerbach and Simberloff, 1989).

The aggregated distribution of $P$. citrella larvae originates from the females' preference to oviposit only in young leaves of the shoots (Garijo and Garcia, 1994; Peña and Schaffer, 1997). Nevertheless, the distribution pattern in shoots was also aggregated, suggesting that even among young leaves, some are preferred. This female oviposition preference could be due to factors as leaf position in the tree crowns and/or to an asynchrony between flushings and the adults' presence in the orchard (Faeth, 1990).

Based upon the obtained results it was verified that the spatial distribution of the citrus leafminer was not homogeneous in the orchards of 'Montenegrina' and 'Murcott', mainly due to plant heterogeneity as a consequence of the organic management. These results indicate that for the monitoring and sampling of $P$. citrella, the spatial distribution pattern should be considered mainly in the tree crown and shoot scales. 

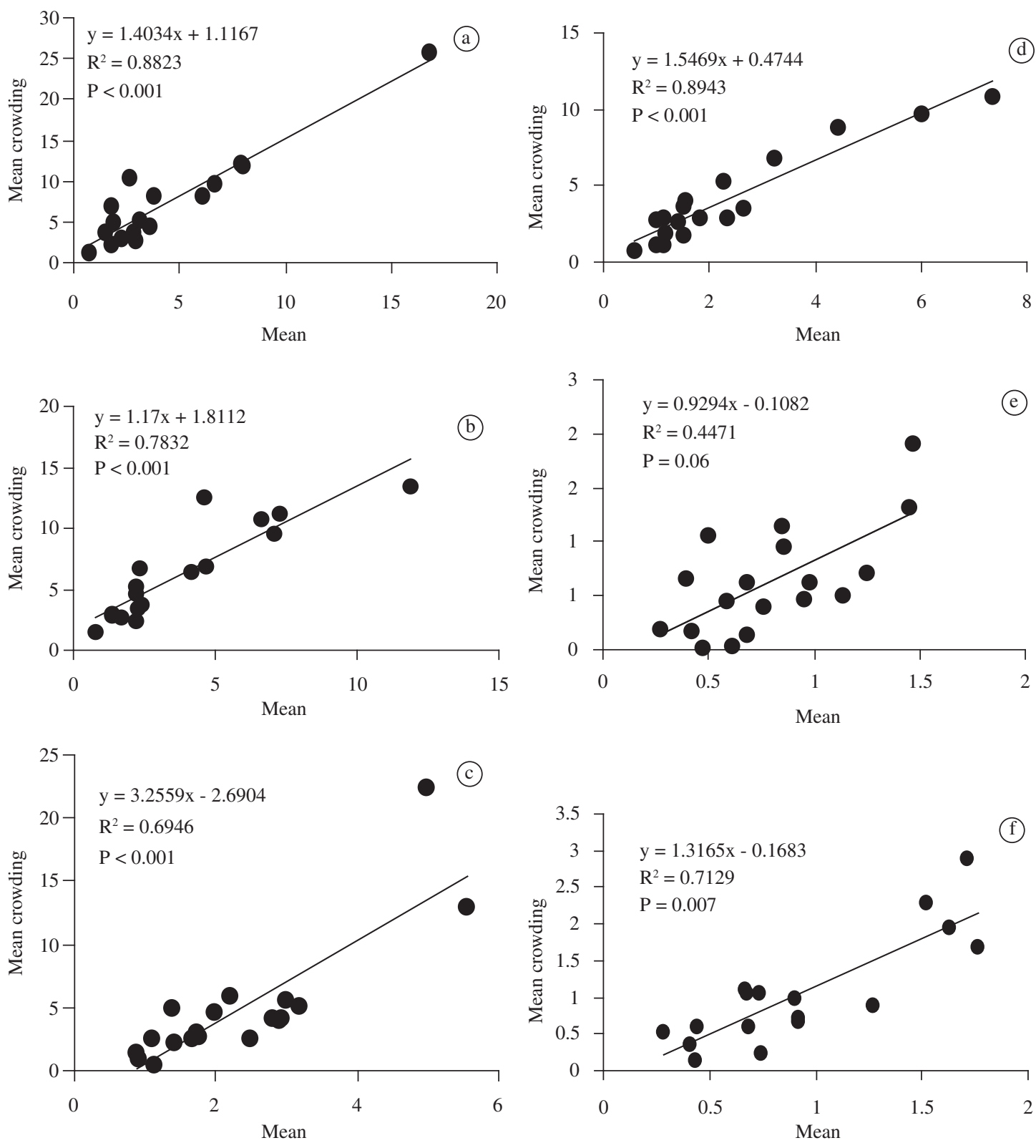

Figure 1. Iwao regression for Phyllocnistis citrella larvae in tree crowns (a,b), shoots (c,d) and leaves (e,f) of Montenegrina tangerine trees (Citrus deliciosa) (a,c,e) and Murcott tangor trees (Citrus sinensis $\mathrm{x}$ Citrus reticulata), (b,d,f), Montenegro $\left(29^{\circ} 68^{\prime} \mathrm{S}\right.$ e $\left.51^{\circ} 46^{\prime} \mathrm{W}\right)$, RS.

Acknowledgments - The authors gratefully, acknowledge Programa RS-Rural for funding and Conselho Nacional de Desenvolvimento Científico e Tecnológico (CNPq) for fellowships conceded to the authors.

\section{References}

AMALIN, DM., PENA, JE., DUNCAN, R., BROWNING, HP. and Mc SORLEY, R., 2002. Natural mortality factors acting on citrus leafminer, Phyllocnistis citrella, in lime orchards in South Florida. BioControl, vol. 47, no. 3, p. 327-347.
AMARAL, AM., 2003. Cancro cítrico: permanente preocupação da citricultura no Brasil e no mundo. EMBRAPA Recursos Genéticos e Agrobiologia, Brasília, 5 p.

AUERBACH, M. and SIMBERLOFF, D., 1989. Oviposition site preference and larval mortality in a leaf-mining moth. Ecological Entomology, vol. 14, no. 2, p. 131-140.

AUERBACH, MJ., CONNOR, EF. and MOPPER, S., 1995. Minor miners and major miners: Population dynamics of leafmining insects. In CAPPUCCINO, N. and PRICE, PW. (eds.), Population dynamics: new approaches and synthesis, Academic Press, California. 
CHAGAS, MCM., PARRA, JRP., NAMEKATA, T., HARTUNG, JS. and YAMAMOTO, PT., 2001. Phyllocnistis citrella Stainton (Lepidoptera: Gracillariidae) and its relationship with the Citrus Canker Bacterium Xanthomonas axonopodis pv citri in Brazil. Neotropical Entomology, vol. 30, no. 1, p. 55-59.

DANTAS, IM., 2002. Distribuição espacial e plano de amostragem seqüencial para lagarta do minador-doscitros Phyllocnistis citrella Stainton, 1856 (Lepidoptera: Gracillariidae), em laranjeira Pêra-Rio Citrus sinensis (L.) Osbeck. (PhD Thesis) - Faculdade de Ciências Agrárias e Veterinárias/UNESP - SP, Brazil.

DAVIS, PM., 1993. Statistics for describing populations. In: PEDIGO, LP. and BUNTIN, GD. Handbook of sampling methods for arthropods in agriculture. CRC Press, Boca Raton.

ELLIOTT, JM., 1983. Some methods for the statistical analysis of sampling of benthic invertebrates. Freshwater Biological Association, Cumbria, $176 \mathrm{p}$.

FAETH, SH., 1990. Aggregation of a leafminer, Cameraria sp. nov. (Davis): consequences and causes. Journal Animal Ecology, vol. 59, no. 2, p. 569-586.

GARIJO, C. and GARCÍA, EJ., 1994. Phyllocnistis citrella (Stainton, 1856) (Insecta: Lepidoptera: Gracillariidae: Phyllocnistidae) en los cultivos de cítricos de Andalucía (Sur España): Biología, ecología y control de la plaga. Boletín de Sanidad Vegetal, Plagas, vol. 20, p. 815-826.

HEPPNER, JB., 1993. Citrus leafminer, Phyllocnistis citrella, in Florida (Lepidoptera: Gracillariidae: Phyllocnistinae). Tropical Lepidoptera, vol. 4, no. 1, p. 49-64.

HESPENHEIDE, HA., 1991. Bionomics of leaf-mining insects. Annual Review of Entomology, vol. 36, p. 535-560.
KNAPP, JL., 1995. "Citrus leafminer", Phyllocnistis citrella Stainton: current status in Florida. Univesity of Florida, Gainsville, $35 \mathrm{p}$.

KREBS, CJ., 2000. Ecological methodology. Bennjamin/ Cummings, Menlo Park, $2^{\text {nd }} . e d .654$ p.

MOPPER,S.,FAETH,SH.,BOECKLEN,WJ. andSIMBERLOFF, DS., 1984. Host-specifc variation in leaf miner population dynamics: effects on density, natural enemies and behaviour of Stilbosis quadricustatella (Lepidoptera: Cosmopterigidae). Ecological Entomology, vol. 9, no. 2, p. 169-177.

PEÑA, JE. and SCHAFFER, B., 1997. Intraplant distribution and sampling of the citrus leafminer (Lepidoptera: Gracillariidae) on lime. Journal Economic Entomology, vol. 90, no. 2, p. 458-464.

POOLE, RW., 1974. An introduction to quantitative ecology. McGraw Hill, New York, 525 p.

RAO, KR., PATHAK, KA. and SHYLESHA, AN., 2002. Spatio-temporal changes in the infestation of citrus leafminer, Phyllocnistis citrella Stainton in Meghalaya. Entomon, vol. 27, no. 2, p. 169-178.

RICKLEFS, RE. and MILLER, GL., 2000. Ecology. WH. Freeman and company, New York, $4^{\text {th }}$ edition, $822 \mathrm{p}$.

SCHAEFFER, B., PENA, JE., COLLS, AM. and HUNSBERGER, A., 1997. Citrus leafminer (Lepidoptera: Gracillariidae) in lime: Assessment of leaf damage and effects on photosynthesis. Crop Protection, vol. 16, no. 4, p. 337-343.

SOUTHWOOD, TRE., 1978. Ecological methods, with particular reference to the study of insect populations. Chapman and Hall, London, $2^{\text {nd }}$. ed., 524 p.

VOLPE, A., CASTRO, PRC. and APPEZZATO-DA-GLORIA, B., 1998. Alterações anatômicas causadas pela lagarta minadora nas folhas de tangerineira Ponkan. Laranja, vol. 19, no. 1, p. 27-38. 